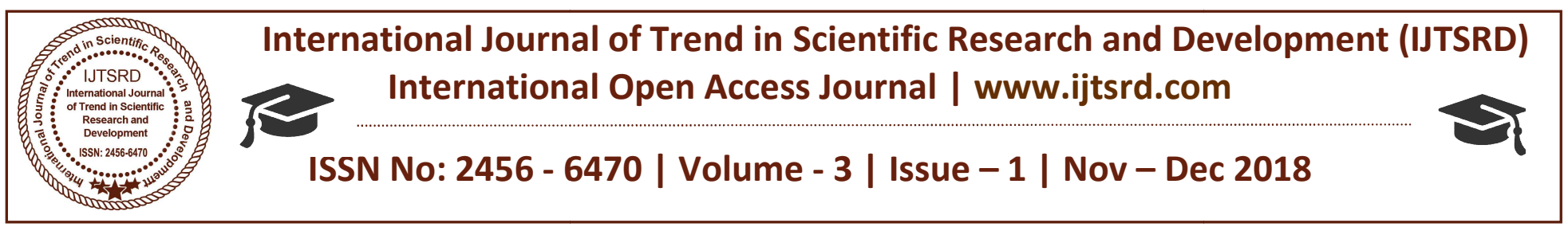

\title{
Marital Rape: A Crime
}

\author{
Pranaya Dayalu, L. K. Swaraj \\ Student, B.B.A.,L.L.B.(Hons.), Shanmugha Arts, Science, Technology \& Research Academy, \\ Thanjavur, Tamil Nadu, India
}

\section{ABSTRACT}

Beauty provokes harassment, the law says, but it looks through men's eyes while deciding what provokes it ${ }^{1}$. Rape is one of the most brutal forms of violation of women's privacy and integrity which is not only a physical offence against the individual but also causes psychological trauma to the victim, their family and in toto the society. This offence is criminalised as per section 375 of IPC. So here the question arises when such an act against a woman is a crime only for unmarried women while it's yet to be treated as a crime for married woman, is this classification of not criminalising such a grave crime for the married women alone justifiable? This paper begins by studying rape and extensively discusses about the controversies surrounding marital rape where the literature on rape is reviewed to draw a nexus between rape and marital rape to prove beyond doubt that all types of rapes are of the same category and is a heinous crime, thus the offenders irrespective of him being a stranger or husband or friend must meet the same ends of justice. The author gives an insight of the life of women who are physically and psychologically affected due to marital rape unable to face justice at the hands of an outmoded society. The author briefs through the legal status of the offence in various constituencies across the world and the commitment of India in International Conventions. The present paper highlights upon the need for criminalisation of marital rape where two of the independent pillars of our democracy has surpassed to the extent of holding that the exception carved out in Section 375(2) of the IPC to be an artificial, arbitrary and discriminatory distinction. The extensive research on rape and marital rape has prompted the author to attract the attention that, "a rapist remains a rapist regardless of his relationship with the victim". The main cerebration of the authors by the referring to

1 Naomi Wolf, The Beauty Myth. above submissions is that marital rape must be criminalised in India.

Keywords: marital rape, conventions, criminalisations, lacunae, fundamental rights violation, article 14, article 21

\section{INTRODUCTION}

Rape is a heinous, brutal and shameful crime which completely strips down a woman's dignity, chastity and pride. "In practice the standard for what constitutes rape is set not at the level of women's experience of violation but just above the level of coercion acceptable to men" said Judith Lewis Herman a psychiatrist and researcher in her book Trauma and Recovery. ${ }^{2}$ In every society there are innumerable crimes. Some crimes are felonies, other are misdemeanours. Crimes have an effect both on the victim and the society at large, one such crime is rape. Women who are raped along with the physical injury have nightmares, panic attacks, waves of self-doubt, and overwhelming sense of distrust. The lives of women who are raped are forever changed, they no longer live their life to the fullest but are just a shell of what they used to be. It is disconcerting enough that such a small proportion of reported rapes make it to court, worst still that so few victims come forth in the first place. Most keep it a dirty secret as the society shuns the victim rather than support her. When a rape case is reported there is a momentary surge where people take to the streets to attain justice for the victim, but within a week everything subsides, and the only change is the increase in the number of rapes. More stringent methods should be brought in to abstain these offenders who not only destroys the

2Trauma and Recovery: Aftermath of Violence- From Domestic Abuse to Political Terror, 1992. 
victim's life, but the entire society is thrown back in a purge due to this horrid offence.

The sacrosanct institution of marriage in India identifies a forever present implied consent to sexual intercourse to hide the horror that happens to many married women saying that there can be no rape in marriage and thereby legalising a grave offence of marital rape which rules Indian women's married life with an iron fist by putting up the façade of a happily married life. Marital rape a crime in many countries and an exception in many more wherein it's a bitter truth that India comes under the latter under the guise that marriage is a sacramental bond and the rape laws make an exception for cases where the perpetrator is the husband.

\section{STATISTICS:}

Though there is a constant increase in crimes and especially rape, the persons punished for the crime are very few. This is mostly due to, not reporting of crimes. According to the NCRB data, during the period 2001-2013, a total of $2,72,844$ cases were reported across the 28 states and 7 UTs in India.

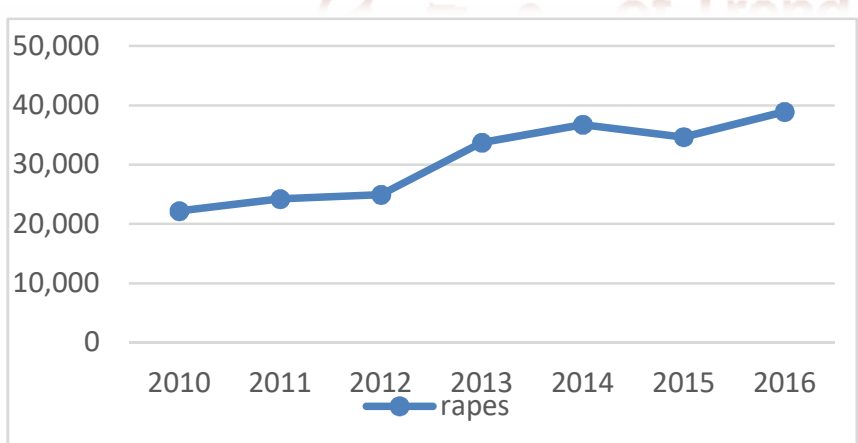

On an average, a little more than 57 rapes are reported to have occurred every day across the country during this 13-year period. That averages to more than 2 rapes across the country, every hour, every day, during the last 13 years. Even if the figure for $2013-$ the year in which the list of offences that constitute rape was expanded - is discounted, the total for the 12-year period between 2001-2012 becomes 2,39,137 cases across all States and union territories. The daily and hourly averages reduce by a few decimal points only. As per the statistical analysis of National Crime Records Bureau (NCRB) 38,947 rape cases were recorded in India in 2016 out of which almost two thirds were committed by fr iends and family. Every 22 minutes an innocent woman is brutally raped in India. Much worse is the situation of married women as marital rape is a crime with a name but without a reality. At present only 52 countries have laws recognising marital rape as a crime.

\section{THE POSITION IN INDIAN LAW}

In India marital rape exists not as de jure but only as de facto, where rape is a criminal offence, but marital rape has neither been criminalised by the legislature nor been recognised by the judiciary as an offence as done in other countries, wherein the judiciary itself is running at cross purposes. Section 375 of the Indian Penal Code which deals with rape, makes an exception in case of marital rape stating that, "Sexual intercourse by a man with his own wife, the wife not being under fifteen years of age, is not rape." By dictionary, conceptual and cultural definition any women can be raped by any man, but the criminal justice system modifies these definitions by not viewing forced intercourse between husband and wife as rape though there is no intelligible differentia. While the law does not criminalise marital rape, a specific form of marital rape is criminalised, i.e. nonconsensual sexual intercourse when the wife and husband are living separately on account of judicial separation or otherwise. Living together raises a presumption that the wife has consented to sexual intercourse by the husband.

As per section 376 of The Indian Penal Code the punishment for rape is imprisonment of either description for a term which shall not be less than 7 years, but which may be for life or for a term which may extend to 10 years and shall also be liable to fine unless the women raped is his own wife and not under 12 years of age. The contrivance of the current legal position can be tracked back to the statement made by Sir Mathew Hale in his Implied Consent Theory which has been adopted into the common law system says that, "the husband cannot be guilty of a rape committed by himself upon his lawful wife, for by their mutual matrimonial consent and contract the wife hath given up herself in this kind unto her husband, which she cannot retract." Though the criminalisation of marital rape is a much sought out topic there has been very few outcomes for the same as the judiciary is at a standoff against itself constantly.

The common misconception prevailing is that it is not rape when a husband has forced sexual intercourse with his wife without her consent because once married the wife has completely given herself to her 
husband as his own as if she is a property and not a human. Criminalising marital rape is still a far-fetched dream in India which is hidden behind the iron curtains of a patriarch society. Finkelhor ${ }^{3}$ has said, "Rape is traumatic not because it is with someone you don't know, but because it is with someone you don't want-whether stranger, friend or husband."

The Hon'ble Supreme Court in Shri Bodhisattwa Gautam vs. Miss Subhra Chakraborty ${ }^{4}$ held that, rape is a crime against basic human rights and is also violative of the victim's most cherished of the Fundamental Rights, namely, the Right to Life contained in Article 21. Yet this very pronouncement is negated due to the non-criminalisation of marital rape.

It is very surprising and disturbing at the same time to understand the Law Commission of India in its 172nd Report held that such an act of wife being put to sexual assault or rape by her own husband being above 18 years of age if made punishable would amount to excessive interference with the marital relationship. On one hand the Supreme Court in numerous judgments has held that, the chastity of a woman is a factor which does not allow her to allege false complaint of rape and that she, being the injured witness, her mere statement would suffice to convict a man for rape. On the other hand, the Law Commission of India proposes to neglect the outcry of the wife who is put to forcible sexual intercourse as excessive interference in the martial relations and that it would cause a dent in the institution of marriage whereas the Supreme Court has emphasized time and again that the character of a woman is not a good defence in the case of rape. Such is the irony which brings us at the glaring inequality that whether a wife above 18 years of age does not deserve her right as discussed in the bear minimum words in Article 21 of the Constitution of India?

\section{THE LACUNAE IN THE INDIAN LAW:}

To many feminists and psychiatrists, rape is less a sexual offence than an act of aggression aimed at degrading and humiliating women. The rape laws do not, unfortunately, take care of the social aspect of the matter and are inept in many respects. Exception to Section 375 of the Indian Penal Code, which states that "sexual intercourse by a man with his own wife,

3License To Rape: Sexual Abuse of Wives (1985).

41996 AIR 922. the wife not being under fifteen years of age, is not rape", falls foul of at least two constitutional provisions.

The first is Article 14, which guarantees equality before law and the equal protection of laws to all persons. The marital rape exception, however, denies to married women the protection of laws against rape, a protection that is extended to unmarried women. In other words, it unequally burdens a class of women solely on the basis of their marital status. The impugned exception of section 375, I.P.C. is classified and completely discriminatory only on the basis of married and unmarried women. Art.14 permits classification but prohibit class legislation. In D.S.Nakara v Union of India5 and in Garg v. Union of India6 the Supreme Court held that the classification, however, must not be arbitrary, artificial, or evasive but must be based on some real and substantial distinction bearing a just and reasonable relation to the object sought to be achieved by the legislation. The classification of the married and unmarried women is irrational and has no nexus to the object to be attained. The provisions of the act at hand claims to preserve the sanctity of the institution of marriage by exempting marital rape from the ambit of punishable offences. In the guise of preserving the institution of family and marriage the individual rights of the women and their right to freedom of choice is trifled.

And secondly, by depriving married women of an effective penal remedy against forced sexual intercourse, it violates their right to privacy and bodily integrity, aspects of the right to life and personal liberty under Article 21. Article 21 of the Constitution of India reads as "no person shall be deprived of his life or personal liberty except according to procedure established by law". In Maneka Gandhi's ${ }^{7}$ case the judiciary gave a new dimension to Article 21 and held that right to live is not merely confined to physical existence, but it includes within its ambit the right to live with human dignity wherein human dignity involves consensual sexual relations where the female is seen in par with the male capable of making her own choices. The same has been further affirmed in all the upcoming judgements such as Francis Coralie v. Union

5 A.I.R. 1983 S.C. 130.

6 A.I.R 1981 S.C. 2138.

7Maneka Gandhi v. Union of India (1978 A.I.R. 597.) 
Territory of Delhi ${ }^{8}$ and People's Union for Democratic Rights v. Union of India ${ }^{9}$. The very exception clause to Sec.375 where married women are stripped of their dignity and made to live a life of submission and shame clearly violates article 21 .

The lead petitioners in the case, the RIT Foundation and the All India Democratic Women's Association $(\boldsymbol{A I D W} \boldsymbol{A})^{10}$ argued that the exception under Section 375 , by discriminating against married women, violates Articles 14 and 15 of the constitution, which prohibit discrimination without an intelligible basis, as well as violating Article 21, which guarantees the right to life and personal liberty, and Article 19, which should guarantee the freedom to express or withhold sexual desire in all consensual contexts. Though the protection of dignity of women is a fundamental duty under the constitution, casting upon every citizen to renounce practices derogatory to dignity of women, offences such as domestic violence and marital rape fail to make it under the scope of dignity.

\section{INTERNATIONAL CONVENTIONS:}

The United Nation's Convention on the Elimination of all forms of Discrimination Against /Women (CEDAW), of which India is a signatory has viewed that this sort of discrimination against women violates the principles of equality of rights and respect for human dignity. CEDAW, at its eleventh session, took the important step of formally including under gender-based discrimination gender-based violence:

"that is violence which is directed against a woman because she is a woman or which affects women disproportionately. It includes acts which inflict physical, mental or sexual harm or suffering, threats such as acts, coercion, and other deprivation of liberty. Gender-based violence may breach specific provisions of the Convention, regardless whether those provisions expressly mention violence."

Women's rights are conceptualized as human rights and a "non-discrimination" model is adopted. Article 1 of the Convention defines discrimination against women as

"any distinction, exclusion or restriction made on the basis of sex which has the effect or purpose of

81981 A.I.R. 746.

91982 A.I.R. 1473.

10 Saint Shri Aharam Mapu v. State of Rajasthan, 2014(2)Crimes162(Raj.) impairing or nullifying the recognition, enjoyment or exercise by women, irrespective of their marital status, on a basis of equality of men and women, of human rights and fundamental freedoms in the political, economic, social, cultural, civil or any other field".

The countries that have ratified or acceded to the convention are legally bound to put its provisions into practice. Though India is a signatory it has failed to accede in accordance to the conventions hence depriving women of their very basic human rights.

This further has been enunciated in the judgment of Independent Thought Vs. Union of India ${ }^{11}$ the bench of Justice Madan Lokur and Justice Deepak Gupta, while deciding the constitutional validity of Section 375(2) of the IPC held that, "sexual intercourse with a girl below 18 years of age is rape regardless whether she is married or not". The Hon'ble court has gone to the extent of holding that the exception carved out in the Indian Penal Code creates an unnecessary and artificial distinction between a married girl child and an unmarried girl child and has no rational nexus with any clear objective to be achieved. The said artificial distinction is contrary to the philosophy and ethos of Art. 15(3), Art. 21 of the Constitution of India and our commitments in International Conventions.

Justice Verma Committee ${ }^{12}$ formed after the Nirbhaya's case ${ }^{13}$ a report recommending changes in the marital rape and keep it in consonance with the UNCEDAW $^{14}$ recommendations. It stated that the signatories should widen the definition of rape in its Penal Code to reflect the realities of sexual abuse experienced by women and remove the exception of marital rape from the definition of rape. Further, Art.253 of the Constitution provides that the Parliament can make any law implementing any treaty or convention made in an international body. Therefore, the Court can very well take into consideration the recommendations made by the UNCEDAW.

11 A.I.R. 2017 S.C. 4904.

12 Justice Verma Report, Gender justice and India 's obligation under International Conventions",

athttp://www.prsindia.org/uploads/media/Justice\%20verma\%20committee/js $\% 20$ verma $\% 20$ committe $\% 20$ report.p df

13 Mukesh v. State of N.C.T. of Delhi. A.I.R. 2017 S.C. 2161

14 UN Committee on the Elimination of Discrimination Against Women, Third Periodic report on India. $\mid 23$ (C.E.D.A.W. C.IND. C.O.3), 2007. 


\section{LEGAL POSITION IN OTHER COUNTRIES:}

- England: Till recently the general rule in England was that the husband cannot be convicted for rape against his own wife as per Sir Hale's theory and were exempted from prosecution for raping their wives based on the understanding that marriage meant implied consent to sex. The turning point for marital rape law in England was in $\boldsymbol{R} v \cdot \boldsymbol{R}^{15}$ through which five Law Lords declared that a husband's immunity from a charge of his wife's rape formed no part of English Law and held the exception clause to be void.

- USA: In USA prior to the 20th century the concept of marital rape exemption was followed. It dates back to 18 th century common law and was articulated by English jurist Matthew Hale. The turning point was the New York case of People Vs. Liberta ${ }^{16}$ where it was finally decided that there was no reason for differentiating between marital rape and non-marital rape. The court noted that "a marriage license should not be viewed as a license to forcibly rape wife with impunity" and struck the marital exemption from the statue in question for violation of the state and federal Constitution.

- South Korea: One of the recent countries to criminalize marital rape is South Korea. Earlier in the 1970's the Supreme Court had upheld the view that there could not be marital rape between a husband and wife, but this thought process has changed over the past four decades. The problem was that according to Korean dictionaries, the word for rape,"ganggan" is defined specifically as a forcible form of non-marital intercourse "ganeum".But the Supreme Court interpreted the meaning of "ganeum" as referring to sexual intercourse in general and therefore by such interpretation wives would be included among the women protected by rape laws.44 All thirteen judges agreed that sexual acts that took place under duress or threat of violence should be punished, including between married couples.

Apart from the above countries 48 countries including Canada, Australia, France, Greece, Pakistan and Sri Lanka have criminalised marital rape.

151991 U.K.H.L. 12.

1664 N.Y.2d 152 (1984)
FOR CRIMINALISATION OF MARITAL RAPE:

The author would like to attract the attention to some of the judgments passed by the judiciary, which has used its wisdom to the discrimination faced by women right from the nascent stage of the drafting of the laws for women till the insensitivity of the society towards it which can be looked at as a classic example of how our scholars uphold the womanhood of a woman and how our society has time and again crushed the woman's wish and will by not recognizing her existence as a woman. The judiciary through its various judgements has asserted on the criminalisation of marital rape, seeing no reasonable distinction between rape and marital rape.

In Suchita Srivastava v. Chandigarh Administration, ${ }^{17}$ the right to make a reproductive choice was equated with personal liberty under Art.21 of the Constitution, privacy, dignity and bodily integrity. It includes the right to abstain from procreating. The discussion on the bodily integrity of a girl and the reproductive choices available to her is important only to highlight that she cannot be treated as a commodity having no say over her body or someone who has no right to deny sexual intercourse to her husband. The human rights of a woman are very much the same whether she is married or not and deserve recognition and acceptance. Right to equality guaranteed under Art.14 is also violated as the differentiation between married and an unmarried woman for the offence of rape is unreasonable. As per the Indian Penal Code, 1860, Sec 375 definition of rape remains the same, i.e. sexual intercourse or sexual penetration when there is lack of consent. The exception of rape is totally a grave violation of fundamental rights of women. Rape per se is an offence against all woman violating her dignity and self-respect in other words; rape is rape immaterial of whether it is done by her husband or a third person.

This Hon'ble Supreme Court in State of Maharashtra v. Madhulkar Narayan, ${ }^{18}$ held that every woman is entitled to sexual privacy and it is not open for any person to violate her privacy as and when he pleased. Every woman is entitled to protect her person if there is any attempt to violate it against her wish and that same protection must be given here also. It is also contended that a woman is not a man's plaything and

17 A.I.R. 2010 S.C. 235.

18 A.I.R. 1991 S.C. 207. 
he cannot take advantage of it in order to satisfy his lust and desires by fooling a woman into consenting to sexual intercourse simply because he wants to indulge in it. In State of Punjab v. Gurmit Singh ${ }^{19}$ it was held that the rapist not only violates the victim's privacy and personal integrity, but inevitably causes serious psychological as well as physical harm. Any right to privacy must encompass and protect the personal intimacies of the home, the family, marriage, motherhood, procreation and child rearing. In Shayara Bano V. Union of India, ${ }^{20}$ Consent for marriage does not give the husband the right to violate his spouse at any point of time such a construction is antithetical to the concepts of right to individual liberty. The exception under section 375 of I.P.C. is not a reasonable classification, and thus, violates the protection guaranteed under Art 14 of the Constitution. It takes away a woman's right of choice and indeed effectively deprives her of bodily autonomy and her personhood. Thus, the classification is unnecessary, unintelligible and thus violates the test of classification under Art. 14.

A woman's personal liberty will also include her right to consent to sexual intercourse. 'Consent as an act of reason accompanied with deliberation, the mind weighing, as in a balance, the good and evil on each side, ${ }^{21}$ also consent supposes three things a physical power, a mental power and a free and serious use of them. The guarantee of human dignity forms a part of Art.21. It must be noted that dignity is linked to personal self- realization and autonomy. It has been stated in the Maneka Gandhi v. Union of India ${ }^{22}$ case that the 'right to live' is not merely confined to physical existence but includes within its ambit the 'right to live with human dignity'. The personal liberty of a woman includes her right to live with human dignity and this includes her right to choose what she wants to do with her body and her right to consent to sexual intercourse. Hence, it is that if consent be obtained by intimidation, force, meditated, imposition, circumvention, surprise, or undue influence, it is said to be treated as delusion and not as a deliberate and free act of the mind. ${ }^{23}$ In Aman Kumar v. State of Haryana, ${ }^{24}$ it was held that it is essential in marital rape that direct and circumstantial

191996 Cri.L.J. 1728.

20 A.I.R. 2017 S.C. 4609

21 Stroud Judicial Dictionary, (Sweet and Maxwell, 9th ed.,2017)

22 A.I.R. 1978 S.C .597.

23 William Jowitt, Jowitt'sDicttionary on English Law, ( II Edn., Vol.1) 24 A.I.R. 2004 S.C. 1497. evidence be taken into consideration. Jury reports and forensic reports are crucial in proving marital rape. Further if the court is not satisfied, it may search for evidence which would lend assistance to her testimony.

Also, the exception under the section guarantees the husband away from conviction when he has a sexual intercourse with his legally wedded wife against her consent. This facilitates the husband to get away from the other offences such as outraging the modesty of a women and causing injury to her when done during the sexual intercourse as he as exempted from the whole act thus cannot be convicted even for those offences. This further is completely against the woman, breaking her more down and violating natural justice.

Affidavits that were filed by the Central Government in Delhi High Court arguing that criminalising of marital rape will destabilise the institution of marriage where contended that this in itself is a mockery as the very offence of marital rape wherein the husband who is supposed to be the protector himself has abused and mistreated his wife, has destroyed the shackles and vows of marriage, hence destabilising it already. The ignorance of the offence further fuels the fire and leaves married women to suffer a life of physical abuse and mental torture in the name of marriage. The legal prescriptions which imply that a wife is the property of her husband which gives the husband permanent right to sexual relations once the wife says "I do" are a reflection of ideology and not reality.

The law is a reflection of what behaviour is ought to be, not what behaviour actually is. In analysing forced sexual relations between spouses, the pervasive ideology of "women as men's chattel" has served to deny women the opportunity to perceive their own sexual victimisation. In a country which is all about the celibacy and purity of women they no less than bat an eye if such a gruesome act happens to a married woman, only because a married woman is a cargo that has already been shipped and sentenced to forever live as her husband's shadow no matter how dark and abusive her married life is. India has laws against rape, seats reserved for women in buses, female officers and special police helplines. But these measures are ineffective in the face of a patriarchal and misogynistic culture. Women are supressed by power and are vulnerable at the hands of their husband and the society as a whole too which preaches that no matter what happens a woman, can 
never desert her family and must forever be imprisoned in her desolate prison of persistent abuse and torture.

\section{AGAINST CRIMINALISATION OF MARITAL RAPE:}

It is popularly contended that marriage is a social institution of great significance which is a legal union of a couple as spouses with legal ability to marry each other by giving their consent. What may appear to be marital rape to an individual wife, it may not appear so to others. As to what constitutes marital rape and what would constitute consented conjugal intercourse needs to be defined precisely before a view on its criminalization is taken. If all sexual acts by a man with his own wife will qualify to be marital rape, then the judgment as to whether it is a marital rape or not will singularly rest with the wife. In an institution of marriage, the husband is not capable of raping his own wife. Under the common law the husband cannot be guilty of rape, for having sexual intercourse with his lawfully wedded wife, for by their mutual matrimonial consent and contract, the wife has already given her consent in this kind to her husband, which she cannot retract. This implies that the husband cannot be prosecuted if he has any kind of sexual intercourse with his legally wedded wife within the wedlock either with her consent or without her consent.

The principle of Art.14 clearly states that the like should be treated alike and not that unlike should be treated alike. As per this it is looked as the classification between the married woman and the unmarried woman under section 375 of the I.P.C. is not arbitrary and unreasonable. All married women are treated equally in this respect and hence there is no class legislation. The very exception has not been classified on a discriminatory basis. The classification has nexus to the object to be attained. Married women and unmarried women cannot be treated as equals. The law is not arbitrary in nature as it is done with objective of protecting the institution of marriage and to prevent the abuse of law by passing a law that is ambiguous in nature. The legislation only provides an exception to a different class of women but does not discriminate against them. Also, in Chiranjit Lal Chowdhuri v. Union of India, ${ }^{25}$ the apex court held that there is always a presumption in favour of the constitutionality of an enactment and the burden is

251951 A.I.R S.C. 41 upon him who attacks it to show that there has been a clear transgression of the constitutional principles. In Municipal Corporation of Thecity v. Jan Mohammed Usmanbhai, ${ }^{26}$ the Supreme Court held that it must be presumed that the legislature understands and correctly appreciates the need of its own people, that its laws are directed to problems made manifest by experience and that its discriminations are based on adequate grounds. The constitution makers of The Constitution of India have taken into consideration every circumstance, need of its own people and has drafted every law intelligibly and discriminated on adequate grounds. Thus, criminalization of rape perpetuates a culture of intolerance and a stigma in the institution of marriage. Reading down the provisions of a statute cannot be resorted to when the meaning thereof is plain, unambiguous and the legislative intent is clear. Thus, the main intention behind the exemption of marital rape to protect the sanctity of marriage by such a classification is reasonable. Therefore, the legislation cannot be struck down as violative of Art. 14 due to arbitrariness or creation of different classes of people.

It is contended that the term "sexual privacy" must be read in a wider aspect when it comes in to the institution of marriage. It is the sexual intimacy between the husband and the wife and they have their rights to perform those rights among themselves. Though Art. 21 of the Indian Constitution talks about the sexual privacy of individuals, privacy cannot be expected in the sexual life of a married couple. It must be understood that once they get married, they become one in a soul and they must not be considered as two individuals anymore. The institution of marriage gives them a conjugal right to be executed between themselves. It does not mean that a license is given to a married person to enforce sexual violence against the other spouse. But it gives them a mutual right of sexual intimacy. So, it must be understood that the act of sexual intercourse by a husband with his wife has its sanctity and one of them executing sexual privacy against the other spouse is unreasonable. Hence the contention of violating Art.21 does not stand.

Also, the other popular contention raised is that when the wife herself is the sole judge of the case it is definitely a total grave violation of natural justice. Any women after a sexual intercourse either with consent or without consent can claim as marital rape,

26A.I.R. 1958 S.C. 1205 
as differentiating a normal intercourse with consent of the wife and a forceful intercourse against her will is almost impossible. With absolutely no appropriate clinical or legitimate method for a clear differentiation it facilitates any women to take undue advantage with the criminalization of this act. In Ashok Kumar v. State of Uttar Pradesh ${ }^{27}$, it was held that evidence of rape cannot be on the sole testimony of the prosecutor, without any corroboration cannot be relied upon. Uncontroverted evidence without medical reports will not hold value in a Court of law and the collection of such evidence gives rise to many practical difficulties which will lead to abuse of the law. In furtherance of the arguments it is herein stated that in the absence of any evidence there is often support to the notion that accusations of marital rape are generally made by women who are vengeful, seeking to gain financially from their husbands.

Sexual intercourse between the husband and wife is an integral part of the marriage and is recognized as one of the chief aims and controlling objects of marriage. The most important objective of marriage is consummation. Consummation or conjugal intercourse or procreation is the main objectives of marriage. The focus is on the contractual terms of the marriage agreement which is presumed to give rise to irrevocable consent to sexual relations. The consent of the wife is inherent in the marriage contract and she is deemed to have given her consent to all the acts of marital sexual intercourse at the time of marriage. This consent shall last throughout that marital life. Hence the consent of the wife is not obtained for every instance of sexual intercourse with her husband. One of the other prominent contention is that there are already sufficient laws present in the Indian legislation in such a way that it protects and safeguards all the rights of a woman. The Domestic violence act, $2005^{28}$ which includes punishment for sexual abuse under section 3, section 354B, section 304B and section 376B of the I.P.C 1860, are some of the major punishments for any man committing offences against a woman. The Indian Divorce Act,

${ }_{28}^{27}$ A.I.R. 1989 All 109.

ncw.nic.in/acts/TheProtectionofWomenfromDomestic ViolenceAct2005.pdf
$1961^{29}$ provides the remedy of divorce to women when she is sexually abused, and violence is used against her by her husband.104 Also, the Act respects the rights of the women and it protects her interests against violence used by her husband. So, criminalizing the husband for having forceful sexual intercourse by bringing him under the term "rapist" is unreasonable. This spoil the sanctity of the marital relationship by and large. The husband would also be deprived of his conjugal rights if marital rape is criminalized.

Even though the above contentions seem vague, unrealistic and absurd the contention against the criminalisation of marital rape is as above.

\section{CONCLUSION:}

The available evidence on marital violence indicates that a number of women are forced into having sexual relations with their husbands through intimidation or physical force. Through the above criticisms it can be clearly seen that this is high time that people start to recognize the crime for what it actually is. Marital rape is a social evil which is existent in the present day and not a reel and as such there is no distinction between rape and marital rape. Veritably marital rape is much worse than rape as the rapist is someone who was supposed to take care of the wife. It is crucial to recognise that this is a major lacuna in criminal law at present defeating the constitutional provisions that grant women equality and autonomy. In order to conclude the authors would like to assert that head-inthe-sand approach towards marital rape would no longer do good and such a twisted social stigma that a wife has entirely submitted herself to the husband mentally and physically through marriage is absurd and marital rape must be criminalised by striking down the exception to section 375 of IPC and bringing in an amendment to include marital rape either under section 375 or as a separate section.

29

jafbase.fr/docAfrique/Ouganda/hindu\%20marriage\% 20\&\%20divorce.pdf 